\title{
STRUCTURAL FEATURES OF NANOMODIFIED CEMENT STONE
}

\author{
Yuri Pukharenko¹, Irina Aubakirova², Vadim Staroverov ${ }^{3}$ \\ ${ }_{1,2,3}$ Chair of Technology of Building Materials and Metrology, \\ Saint -Petersburg State University of Architecture and Civil Engineering, \\ Vtoraja Krasnoarmejskaja ul.4, St. Petersburg, 190005, Russia \\ tsmm@spbgasu.ru
}

\begin{abstract}
The article reviews the effect of mixing water pre-modified with fulleroid nanomaterial on cement paste rheology and cement stone structure. Also $\mathrm{pH}$ value of modified mixing water is determined and its variation under the effect of nanomaterial is shown. Typical acidulation of obtained slurry is noted and time of its activity (aggregative stability) beneficial to formation of cement stone structure is determined. Analysis of the obtained results is evidencing changes in properties of cement systems prepared with the use of nanostructured water, namely increase in cement paste setting time and improvement of its fluidity with rheological properties maintained; enhancement of pore structure with improved uniformity of distribution throughout the volume, leading to increase in strength properties of cement stone.
\end{abstract}

\section{Keywords}

Fulleroid material, nanomodifier, cement stone structure, cement composites: structure and properties, nanomodifiers

\section{Introduction}

For a long time, cement science was aimed at studying of cement and cement fillers' properties and their efficient usage. Less attention was paid to mixing water. At the same time, water, being a structural component of raw mixture, is of importance in formation of cement composite structure and properties.

In prior years methods were developed for mixing water structurization with magnetic and electromagnetic field exposure, electrochemical, acoustic and plasma activation, etc. (Bad'in, 2006; Leonov, 1997; Yudina, 2005). However, methods of physical activation of mixing water were not of extensive use due to objective difficulties at the stage of industrial implementation. For example, mixing water activated with magnetic field completely loses its re-acquired properties in a very short period of time. At that, extra fine equipment adjustment is required for the purpose of effective magnetic activation. In case of electrochemical activation of water, the main problem is in setting of effective electrochemical processing parameters (electric field intensity, current density, processing time) as they are dependent from various factors (properties of materials in use, physical and chemical properties of source water, ambient temperature). Such parameters can only be determined under workshop conditions by experiments. But the most essential problem impeding methods of physical activation is in need of processing lines' upgrade with costly equipment for water activation and complete revision of operating procedures.

Due to development of nanotechnology (Bal'makov, 2005; Gusev, 2005; Korolev, 2006) new possibilities can be considered for influencing water structure and properties (Kovaleva, 2008; 2006). Therefore, targeted control of structure forming processes and properties of cement composites that represent a complex multistage system (including a nano-level as well) is considered as upto-date and promising way of concrete technology development.

\section{Materials and Methods}

Within the framework of experimental studies, effect of fulleroid material (Fig. 1) consisting of 20$200 \mathrm{~nm}$ particles was investigated. Working slurries were made based on distilled water processed with the use of distillation unit of DU-23 type by dilution of initial (highly concentrated) slurry down to required concentrations. 
To determine any changes in water, upon introduction of carbon clusters, $\mathrm{pH}$ value was measured using $\mathrm{pH}$ meter of Delta 320 type.

In order to investigate the effect of nanostructured mixing water, experiments were carried out to determine cement paste setting time and fluidity as well as cement stone structure and properties as applied to various cements: PC 500-D0 (JSC Oskolcement), PC 400-D0 (CJSC Belgorodskiy cement), PC 500-D0-N (JSC Mordovcement), CEM I 42.5R (Holcim, Germany). The cement compositions under investigation varied in water-cement ratio; hardening conditions and modes.

\section{Results}

The results of $\mathrm{pH}$ value measurements at different nanomodifier concentrations are shown in Fig. 2.

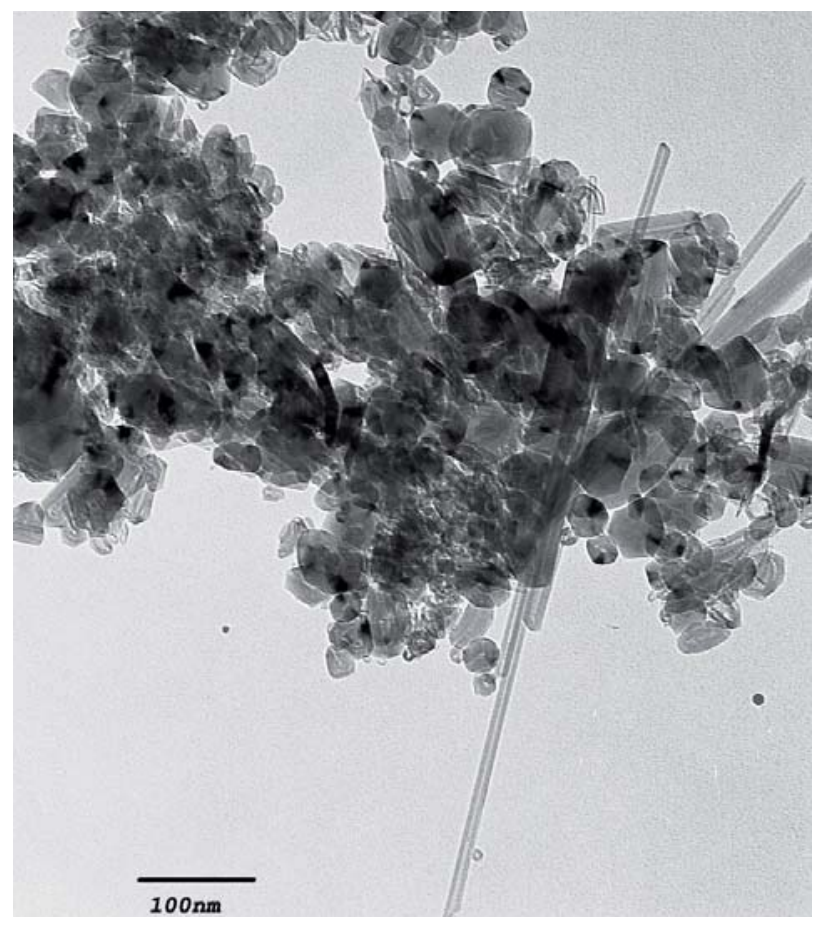

Fig. 1. Fulleroid material

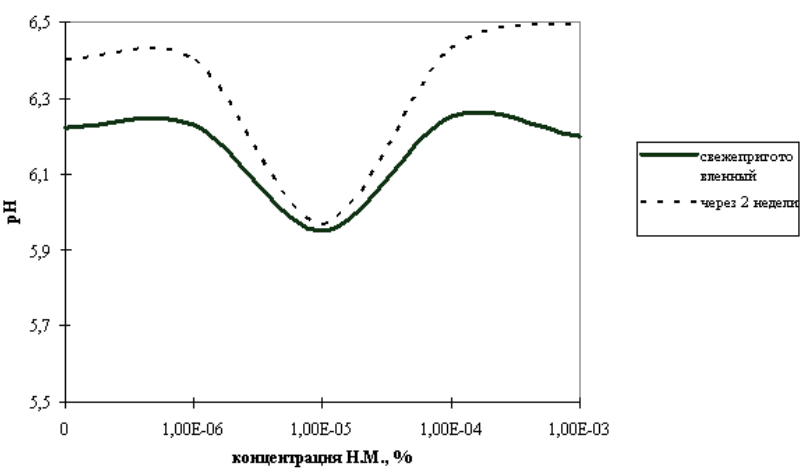

Fig. 2. Change in $\mathrm{pH}$ value of nanomodified mixing water

The test results given in Table 1 were obtained for samples of CEM I 42.5R Portland cement (Holcim, Germany) with water-cement ratio (W/C) of 0.26 corresponding to normal density.

The strength test results obtained for nanomodified cement stone are shown in Fig. 3 and 4 .

\section{Summary}

The effect shown in Fig. 2 is evidencing quite a narrow nanomodifier concentration range iin which the peak of slurry $\mathrm{pH}$ decrease occures.. This effect can be explained only by change in ionic product of water, caused by sorption of hydroxyl groups at the surface of nanoparticles. As it is known, the degree of water electrolytic dissociation under normal conditions is relatively low $\left(10^{-9}\right.$ at the temperature of $+20{ }^{\circ} \mathrm{C}$ ) (Zatsepina, 1987). At that, concentration of hydroxonium ions $\left[\mathrm{H}_{3} \mathrm{O}^{+}\right]$and, therefore, of hydroxyl groups $\left[\mathrm{OH}^{-}\right]$equals to $10^{-7}$. In simplified form, reactions of water dissociation are described by the following scheme:

$$
\left[\mathrm{H}_{2} \mathrm{O}\right] \underset{\leftarrow}{\stackrel{2}{\leftarrow}}\left[\mathrm{H}_{3} \mathrm{O}^{+}\right]+\left[\mathrm{OH}^{-}\right]
$$

At particular concentration of nanomodifier, the above dynamic equilibrium displaces to the right due to sorption of $\left[\mathrm{OH}^{-}\right]$ions at the surface of nanoparticles.

Table 1

Effect of nanostructured water on cement paste and stone properties

\begin{tabular}{|l|l|l|l|l|l|l|}
\hline \multicolumn{2}{|c|}{ Properties } & \multicolumn{5}{c|}{ Concentration of nanomodifier in mixing water, \% } \\
\cline { 2 - 7 } & 0 & $10^{-7}$ & $10^{-6}$ & $10^{-5}$ & $10^{-4}$ & $10^{-3}$ \\
\hline Setting time, min: & 200 & 200 & 225 & 210 & 235 & 220 \\
- start & 230 & 235 & 250 & 250 & 270 & 245 \\
- end & & & & & & \\
\hline Fluidity determined by flow in shaker & & & & & \\
apparatus, mm & 160 & 159 & 162 & 173 & 168 & 155 \\
- upon preparation & 152 & 150 & 159 & 156 & 163 & 154 \\
- in 60 min & 115 & 122 & 134 & 140 & 142 & 139 \\
- in 150 min & 0.395 & 0.377 & 0.356 & 0.265 & 0.332 & 0.315 \\
\hline Water sorption at capillary rise, $\mathrm{kg} /\left(\mathrm{m}^{2} \mathrm{~h}^{0.5}\right)$ & 0.288 & 0.259 & 0.295 & 0.312 & 0.317 & 0.297 \\
\hline Uniformity of pore size, $\alpha$ & 1.623 & 1.652 & 1.595 & 1.611 & 1.619 & 1.601 \\
\hline Average pore size, $\lambda$ & & & & & & \\
\hline
\end{tabular}


Change in ultimate bending strength of cement stone (PC 500-D0, JSC Oskolcement)

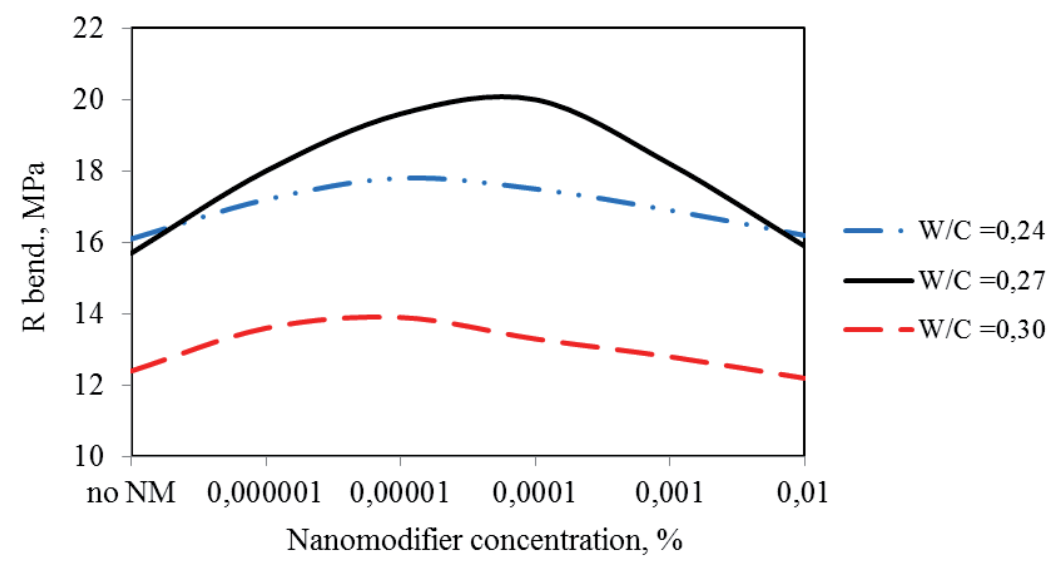

Fig. 3. Ultimate bending strength of nanomodified cement stone

Change in ultimate compression strength of cement stone (PC 500-D0, JSC Oskolcement)

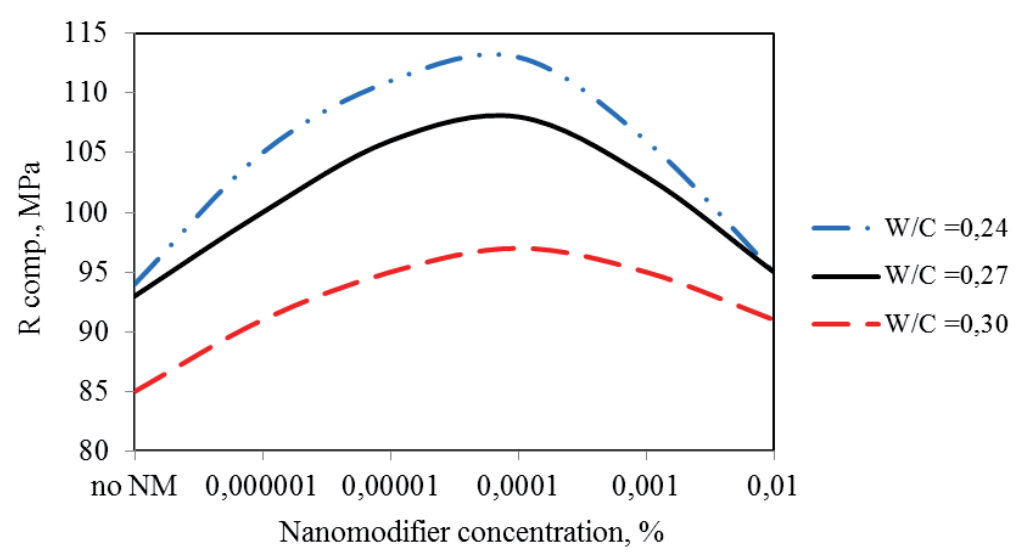

Fig. 4. Ultimate compression strength of nanomodified cement stone

Obviously, carbon nanoclusters act like stabilizers of water system self-organization process. Continuation of the process under investigation leads to generation of a secondary structure, i.e. fractal volume mesh (Fig. 5) which is located throughout the entire volume of water and locally changes concentration of hydroxyl groups, resulting in volumetric $\mathrm{pH}$ change; and at the stage of cement stone formation it allows to organize crystallization process and decrease size of crystalline hydrates (Bal'makov, 2005; 2006).

Noted acidification of slurry has beneficial effect on processes of cement stone formation, as in this case neutralization reaction can occur between the most soluble form of calcium hydroxide and active hydroxonium ions. Water is the product of this reaction and it further couples with less active products of portland cement hydration. At that, new water generation as a product of chemical reaction within the system will facilitate cement paste plasticization. Further increase in nanomodifier concentration leads to its sorption ability decrease due to aggregation of its active particles and, consequently, of its total surface, that causes $\mathrm{pH}$ value increase.

In our case an approved method (Sheykin, 1979) was used to determine indirect porosity characteristics: $\alpha$ - uniformity of pore distribution, $\lambda$ - average pore size. Using the obtained values, it is possible to calculate capillary size, but in our case precise determination of size in not of importance. Change in $\lambda$ describes differences in capillary size only. I.e., $\lambda$ describes an average capillary size and a describes uniformity of capillary size distribution. The given parameters allow to qualitatively describe differential porosity and perform quantitative evaluation of the broad range of pore and capillary sizes.

Analysis of the obtained results shows more uniform distribution of pores throughout the volume of induraed modified cement stone. It is proven by increase in $\alpha$. At the same time, average pore size slightly reduces (decrease in $\lambda$ ).

Thus, pore structure of nanomodified stone undergoes changes: generation of large amount of microcapillary is observed in comparison with 


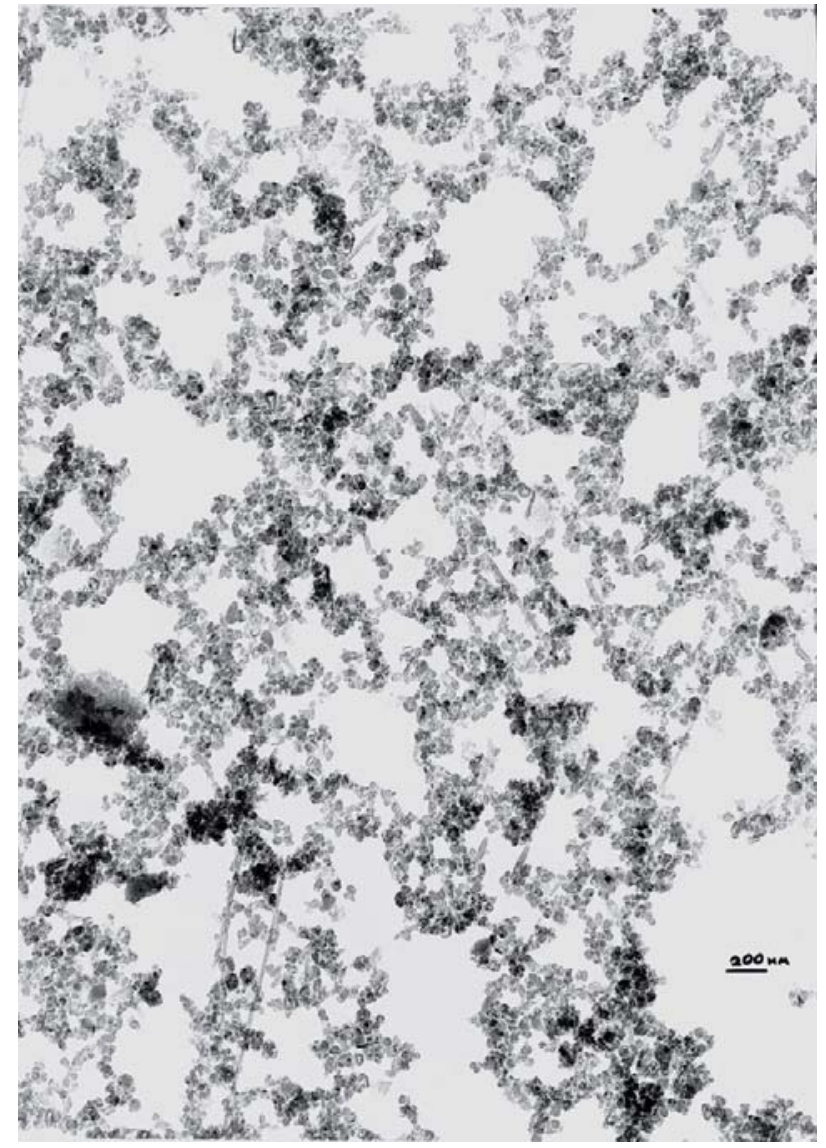

Fig. 5. Fractal mesh

ordinary cement stone that contains larger amount of macrocapillary. At that, pore space in nanomodified cement stone is more ordered. However, it should be noted that similar to changes in physical and chemical properties of water, behavior of pore space variability in nanomodified cement stone is of polyextreme character. But despite nonlinear dependence of generating capillary from nanomodifier concentration, significant change was determined in generating pore space upon cement mixing with slurries of different nanomodifier concentration.

Such significant changes in behavior of nanomodified cement stone pore structure cannot be explained only in terms of introduction of nanosized carbon objects, which are physically located in capillaries, due to insufficient quantity of nanomodifier introduced into cement system in order to stop macrocapillary growth. In this case generation of the large amount of microcapillaries is affected by change in hydration process. This fact was proven earlier by the example of cement paste setting time and fluidity.

Analysis of the obtained results shows change in properties of cement systems prepared with the use of nanostructured water, and the following can be concluded:

- when concentration of nanomodifier in mixing water equals $10^{-4} \ldots 10^{-6} \%$, that correspond to the range of decreased $\mathrm{pH}$, some improvement of cement paste setting time and fluidity occurs as well as maintaining of its rheological properties in time;

- within the same concentration range a tendency to improvement in cement stone strength properties within $15-20 \%$ is observed (depending on cement type, water-cement ratio and other factors).

It should be noted that effective concentration of nanomodifier in mixing water changes depending on types of used fulleroid compounds and, thus, results in change of cement system properties. Therefore, there is a possibility of adjustment using complex of required cement paste and stone properties and, at the same time, using concrete mixture and concrete properties (Kovaleva, 2008).

\section{References}

Bad'in G, Legalov I (2006) Vliyanie magnitnoy obrabotki vody na svoystva tsementnykh rastvorov i betonov [Effect of water magnetic processing on properties of cement mortar and concrete]. Populyarnoe betonovedenie [Popular Cement Science], 4(12): pp. 85-87. (In Russian)

Bal'makov M, Pukharenko Yu (2005) Nanokompozitsionnoe materialovedenie [Nanocomposites material science]. Vestnik grazhdanskikh ingenerov [Bulletin of Civil Engineers], 3(4): pp. 53-57. (In Russian)

Gusev A (2005) Nanomaterialy, nanostruktury, nanotekhnologii [Nanomaterials, nanostructures, nanotechnologies]. FIZMATLIT publishing office, Moscow, Russia. (In Russian)

Zatsepina G (1987) Fizicheskie svoystva i struktura vody [Physical properties and structure of water]. Publishing office of the Moscow State University, Moscow, USSR. (In Russian)

Kovaleva A, Belyaeva Zh, Aubakirova I, Staroverov V (2008) Opyt promyshlennogo primeneniya nanomodifitsirovannykh betonnykh smesey [Experience in industrial application of nanomodified concrete mixtures]. Populyarnoe betonovedenie [Popular Cement Science], 3(23): pp. 28-29. (In Russian)

Korolev E, Bazhenov Yu, Beregovoy V (2006) Modifitsirovanie stroitel'nykh materialov nanouglerodnymi trubkami i fullerenami [Modifying of construction materials with nanocarbon tubes and fullerenes]. Structural Materials - Science. No. 8: 2-4. (In Russian) 


\section{Architecture and Engineering Volume 1 Issue 1}

Leonov B (1997) Elektrokhimicheskaya aktivatsiya vody i vodnykh rastvorov: proshloe, nastoyashchee, budushchee [Electrochemical activation of water and water solutions: past, present and future. Sbornik trudov Pervogo mezhdunarodnogo simpoziuma po jelektrohimicheskoj aktivacii [Collected papers of the First International Symposium for Electrochemical activation]. VNIIIMT(Russian Scientific and Research Institute for Medical Engineering ), Moscow, Russia.

Pukharenko Yu, Nikitin V, Letenko D (2006) Nanostrukturirovanie vody zatvoreniya kak sposob povysheniya effektivnosti plastifikatorov betonnykh smesey [Nanostructurization of mixing water as a method of efficiency improvement for cement mixtures plasticizers]. Stroitel'nye materialy - Nauka [Structural Materials - Science], No.8: pp. 11-13 (In Russian)

Sheykin A, Chekhovskiy B, Brusser M (1979) Struktura i svoystva tsementnykh betonov [Structure and properties of cement concretes]. Stroyizdat, Moscow, USSR. (In Russian)

Yudina A (2005) Betonnaya smes' na vode zatvoreniya, predvaritel'no obrabotannoy elektricheskim polem [Concrete mixture prepared with the use of mixing water pre-processed with electric field]. Populyarnoe betonovedenie [Popular Cement Science], 5(7): pp. 65-77. (In Russian) 